\title{
Auditory Training in the Aural Rehabilitation of Older Adults: Utopia or Reality?
}

\author{
Carla Matos Silva ${ }^{1,2 *}$ \\ ${ }^{1}$ Instituto Politécnico de Coimbra, ESTeSC - Coimbra Health School, Departamento de Audiologia, Portugal \\ ${ }^{2}$ School of Arts and Humanities, Centro de Linguística da Universidade de Lisboa, University of Lisbon, Portugal
}

Submission: July 28, 2020; Published: August 03, 2020

*Corresponding author: Carla Matos Silva, Instituto Politécnico de Coimbra, ESTeSC - Coimbra Health School, Departamento de Audiologia, 3046-854 Coimbra, Portugal

\section{Opinion}

The aging of population and the increase in average life expectancy are a challenge for informal caregivers, health professionals and society in general. These age-related changes are manifested by the degradation of anatomical, physiological, and auditory structures and functions. The aging process brings changes that can influence auditory processing. Age-related hearing loss, presbycusis, is caused by a bilateral and progressive degradation of hair cells in the inner ear, which affects mainly the basal area of the cochlea. One of the main difficulties in the elderly diagnosed with presbycusis is the discrimination of the sound stimulus, especially in acoustically unfavorable environments. The auditory pathways of the central nervous system are also affected with aging, worsen the difficulty in decoding verbal and nonverbal stimuli. The lack of speech perception, especially in reverberant environments or with competing noise, leads to communication difficulties and, as a result, other difficulties arise, such as social isolation, depression, and anxiety which brings direct repercussions on the quality of life of the elderly [1].

To minimize the effects of the hearing loss, the elderly should be referred to aural rehabilitation plans using hearing aids. These can improve hearing but are not always able to restore central auditory function. Thus, it is important to reflect on current aural rehabilitation protocols that must include an audiological assessment of the entire auditory system once the auditory information covers the peripheral auditory system and the auditory pathway up to the cortex, allowing the subject to detect, discriminate, locate, identify and recognize the sound in silent and noisy environments, and finally interpret it [2]. The inclusion of central auditory processing evaluation in the elderly's aural rehabilitation protocol allows the audiologist to diagnose the central auditory processing disorders and identify the impaired skills to implement auditory training in these same plans.

Auditory training is a set of plans and/or acoustic tasks that aim to activate the auditory system, as well as other related systems due to the neuroplasticity of the central auditory nervous system [3]. That is, auditory training can promote changes in nerve cells, according to environmental influences regardless of age. This type of training can be divided into two types: the formal training that is carried out with the presence of an audiologist with acoustically calibrated equipment in an environment that can be controlled acoustically; and the informal training that can be carried out by the individual at home, through games that will permit him to stimulate the auditory skills. Both trainings consist in the repetition of several tasks adding a higher degree of difficulty after concluding each stage [4].

The success of an aural rehabilitation plan involves a rigorous assessment of the clinical and audiological situation, including the assessment of central auditory processing, the correct selection and adaptation of hearing aids according to individual needs, and if necessary, it is possible to consider other types of complementary interventions to the adaptation of hearing aids, considering auditory training as one of the essential clinical interventions. The benefits of auditory training in the elderly can be seen immediately after the training sessions and are maintained after 3 months [5].

Although there are several studies in the literature that prove that auditory training improves the performance of speech perception even in unfavorable acoustic conditions, auditory memory and the processing speed of verbal and non-verbal information, reducing auditory effort both at the neural and perceptual [5-7], there is still no widespread agreement in their inclusion in aural rehabilitation plans. Perhaps because of the associated costs. But do the benefits of auditory training in the elderly in medium or long term, outweigh the costs? Why is there scientific evidence if we do not apply it in clinical practice?

Considering all the available evidences, we must recognize, as a crucial need, the implementation of audiological protocols in senior population, including the central and peripheral evaluation, to guide the elderly to tailored aural rehabilitation plans including 
auditory training sessions. The whole process will ensure the success of the aural rehabilitation plans, contributing to the enhanced communication abilities and to significant improvement in the overall quality of life. Auditory training, in senior population, cannot be a utopia or unnecessary intervention, but must be a real intervention that can change and dignify their lives.

\section{Conclusion}

Auditory training should be used as a tool to support aural rehabilitation in senior population by improving their hearing skills. Furthermore, studies are needed on the persistence of the effects of auditory training over time, to determine whether its application should be continuous or repeated from time to time to optimize long-term benefits.

\section{References}

1. Moradi S, Wahlin A, Hällgren M, Rönnberg J, Lidestam B (2017) The efficacy of short-term gated audiovisual speech training for improving auditory sentence identification in noise in elderly hearing aid users. Front Psycho 8(368): 1-10.

2. Musiek F, Baran J (2007) The auditory system: anatomy, physiology, and clinical correlates. Boston, MA: Pearson.

3. Filippini R, Brito NFS, Neves Lobo IF, Schochat E (2014) Manutenção das habilidades auditivas pós treinamento auditivo. Audiol Commun Res 19(2): 112-116.

4. Tye Murray N, Sommers MS, Mauzé E, Schroy C, Barcroft J, et al. (2012) Using patient perceptions of relative benefit and enjoyment to assess auditory training. J Am Acad Audiol 23: 623-634.

5. Silva C M, Fernandes C, Rocha C, Pereira T (2020) Study of Acute and Sub-Acute Effects of Auditory Training on the Central Auditory Processing in Older Adults with Hearing Loss-A Pilot Study. Int Environ Res Public Health 17: 4944.

6. Stropahl M, Besser J, Launer S (2019) Auditory Training Supports Auditory Rehabilitation: A State-of-the-Art Review. Ear Hear 41(4): 697-704.

7. Morais AA, Rocha Muniz CN, Schochat E (2015) Efficacy of auditory training in elderly subjects. Front Aging Neurosci 7(78): 1-9.

\section{Your next submission with Juniper Publishers will reach you the below assets}

- Quality Editorial service

- Swift Peer Review

- Reprints availability

- E-prints Service

- Manuscript Podcast for convenient understanding

- Global attainment for your research

- Manuscript accessibility in different formats ( Pdf, E-pub, Full Text, Audio)

- Unceasing customer service

Track the below URL for one-step submission https://juniperpublishers.com/online-submission.php 